\title{
Concepts and issues in marine ecosystem
}

\section{management}

\author{
P.A. LARKIN \\ The Vorth Pacific Univirsities Marine Mammal Research Consortium, Fisheries Centre.University of British \\ Columinia, Room 18. Hut B-3. 6248 Biological Sciences Road, Vancouver. BC. CanadaV6T IZ4
}

\begin{abstract}
Ecosystem management means different things to different people, but the underlying concept is similar to that of the long-standing ethic of conservation. Current interest in marine ecosystem management stems from concerns about overexploitation of world fisheries and the perceived need for broader perspectives in fisheries management. A central scientific question is whether the effects of harvesting (top down) or changes in the physical environment (bottom up) are responsible for major changes in abundance.

Historically, ecology, fisheries biology, oceanography, fisheries management and the fishing industry have gone somewhat separate ways. Since the 1980 s, increasing attention has been given to multispecies aspects of fisheries, the linkages between oceanography and fish abundance and more holistic approaches to fisheries management.

Sorting out the causes and effects of fluctuations in fish abundance is complicated by the lack of reliability of fisheries statistics. Discards, dishonesty and the inherent logistic difficulties of collecting statistics all combine to confuse interpretation. The overcapacity of fishing fleets and their unrestricted use are widely recognized as a contributing cause to overfishing and declines in fish stocks in many parts of the world.

Ecosystem management, as shorthand for more holistic approaches to resource management, is, from a fisheries management perspective, centred on multispecies interactions in the context of a variable physical and chemical environment. Broader perspectives include social, economic and political elements which are best considered pragmatically as a part of the context of fisheries management.

Objectives in marine ecosystem management are varied. From a biological perspective, an underlying principle of management is commonly assumed to be a sustained yield of products for human consumption. Whether that should be taken to mean that the yield - should always be of the same products is less certain. Fishing commonly changes the relative abundance of species of fishes. Thus, a biological objective should specify the species mix that is desired.

Concern for the maintenance of global diversity has generated a substantial literature on threatened and endangered species. In general, it has not been considered likely that marine fish species could be rendered extinct and greatest attention has been given to marine mammals, sea birds and sea turtles. The provision of marine parks and sanctuary areas are obvious first steps in providing a measure of protection, at least for the less widely ranging species.

Related to the current concepts of ecosystem management are expressions such as
\end{abstract}


ecosystem health and ecosystem integrity which are given a wide range of different meanings, none of which are readily translated into operational language for resource management. These and similar expressions are best assessed as rhetorical devices. The essential components of ecosystem management are sustainable yield, maintenance of biodiversity and protection from the effects of pollution and habitat degradation.

Theory for marine ecosystem management has a long history in fisheries and ecological literature. Ecological models such as Lotka-Volterra equations, ECOPATH, trophic cascades and chaos theory do not give practical guidance for managcmcnt. Fleet interaction and multispecies virtual population analysis models hold more promise for fisheries managers.

Alaska provides particular opportunities for developing new concepts in fisheries management. Statistics of catch are good, stock assessments are at the state-of-the-art level and management has been prudent. Debate is active on the causes of substantial changes in abundance of many species including marine mammals, because substantial changes in the fisheries have been accompanied by major changes in oceanographic conditions.

As elsewhere, the resultant changes may be a consequence of top-down and bottom-up effects. The bottom part is beyond human control, and ecosystem management is centred on managing the top-down or fisheries component in the context of special measures of protection for particular species.

Whether that is a realistic goal depends in part on how much special protection is to be afforded to which species. Marine mammals, for example, are given high priority for special protection, but like fisheries they too may have significant roles in shaping the structure of marine ecosystems. Eventually, ecosystem management must come to grips with the question of how much protection of particular species is desirable in achieving optimal use of living marine resources.

\section{Contents}

Introduction

page 140

A bit of history

Ecosystem management - what is it?

$\begin{array}{lr}\text { Some ecoiogicai models for marine ecosystem management } & 150\end{array}$

$\begin{array}{ll}\text { Practical models for marine ecosystem management } & 154\end{array}$

$\begin{array}{lr}\text { Concluding comment } & 157\end{array}$

$\begin{array}{ll}\text { Acknowledgements } & 158\end{array}$

References $\quad 159$

\section{Introduction}

Ecosystem management means different things to different people, but the underlying concept is as old as the hills. In the words of Egolfs Bakuzis (1969), 'Fragments of this concept can be traced back to the ... commonsense knowledge of hunters and farmers in different parts of the world. The vocabulary has changed, thoughts have deepened, technical solutions have developed, and theories have been tried to clarify the concept; this work will continue in the future.' That quote appears in the book edited by George Van 
Dyne (1969) entitled The Ecosystem Concept in Natural Resource Management. At that time, the International Biological Program was just nicely under way and various kinds of mathematical models of ecosystems were being developed. All ecosystems, whether conceived for agriculture, forestry, fisheries or wildlife, were seen to share common fundamental characteristics of energy flow, trophic levels, species interaction, stability and resilience. In less well-articulated language, the same kinds of appreciation spawned the conservation ethic of the first half of this century, and as Bakuzis observed, also underlay the sound husbandry of countless generations that went before.

Although all ecosystems have some fundamental similarities, there are some important differences. For example, for those that are land based, regional ecosystems are defined by major vegetation characteristics, hence the prairie ecosystem, the boreal forest ecosystem, the desert ecosystem and so on. Within each of these regional ecosystems there are lesser ecosystems, each characterized by a particular complex of vegetation. A similar hierarchy applies to the world's oceans but it is not based on vegetation characteristics.

Sherman (1993) recognizes 49 large marine ecosystems (LMEs), each occupying a coastal area of the order of $200000 \mathrm{~km}^{2}$ with distinct characteristics of depth, oceanography, productivity and populations of organisms that are linked in trophic food chains and webs. Taken together, the coastal LMEs produce $95 \%$ of the annual world catch of marine fisheries. A 50th LME could be assigned to the mid-ocean areas, which are deep and unproductive (blue is the colour of the desert in the ocean). Within each of these regional ecosystems, lesser ecosystems may be delineated, such as those of estuaries, bays or coral reefs. Ail the LMEs taken together constitute a global marine ecosystem.

The development of the LME concept is a contemporary crystallization of broader perspectives in fisheries management. Overexploitation of major stocks is now occurring in most fisheries of coastal zones despite the declaration of 200 mile zones. World catch has peaked at less than 100 million tonnes, and of that total, an increasing amount is coming from aquaculture (Alverson and Larkin, 1992). Marine fisheries account for 53 million tonnes. An unreported bycatch may amount to another 29 million tonnes (Alverson et al., 1994). In many parts of the developing world, a dearth of reliable statistics, a shortage of trained personnel and an inadequate institutional infrastructure all contribute to weak management. Many of the fisheries of the more developed countries are also in trouble. Many of the foreign fleets of the pre-200 mile zone era have either continued to fish under licence and/or been replaced by joint venture or domestic vessels. Many receive subsidies of one kind or another. Some foreign fleets are chronic violators of 200 mile limits and of agreements on quotas for stocks that migrate beyond 200 mile limits. More, rather than less, stock is fully or overexploited in United States waters and fisheries are seen to be at a 'critical juncture' (Sissenwine and Rosenberg, 1993). Canadian Atlantic fisheries are in a depleted state and a moratorium has been placed on fishing for cod (Gadus morhua, Gadidae). Similar examples of decline can be drawn from most other parts of the world's oceans. Some new approaches are evidently needed.

In consequence, increasing attention is being given to management of living marine resources on an ecosystem scale. The hope is that by coupling understanding of the processes of physical, chemical and biological oceanography with insights into the population biology and interactions of the various species of the fish community; and further, by considering humans as part of ecosystems, it may be possible to better 
manage the potential resources on a sustainable basis. These are not new ideas. The hard scientific question at the core is whether changes in the physical environment (bottom up) or the effects of harvesting (top down) are responsible for major changes in abundance, and that question, in one form or another, is a perennial source of debate in fisheries management.

The discussion that follows'is aimed at assessing the state of understanding of marine ecosystem dynamics and evaluating whether it is sufficient for practical application in fisheries management. Before addressing that issue it is useful to briefly sketch some of the developments in the relevant science and in world fisheries and to clarify just what is meant by various users of the term 'ecosystem management'.

\section{A bit of hislory}

From the late 1940s to the early 1960s, centre stage in theoretical ecology was occupied by the debate over what factors regulated the abundance of animals, those that increased in intensity as abundance went up, such as predation or disease, or those that acted independently of density, such as the climate. Most of the debate was centred on birds and mammals, for which density dependence seemed more the rule, and on insects, for which climate was dominant. The discussion among the ecologists (chiefly Australian) eventually fizzled out in semantics, more or less with the conclusion that the physical environment set the stage on which the biological drama took place. The excellent little book by Slobodkin (1963) captured the essence of the population biology of the day. Rather little attention was given to fish or fisheries, but the obvious parallel was whether oceanographic conditions or biological factors were determining fish abundance.

Fisheries biologists, in another solitude, were struggling with their version of the same problem in the form of what were called stock and recruitment relationships, which described changes in abundance from one generation to the next. The two common versions were those of Ricker (1954) and Beverton and Holt (1957). Both assumed density-dependent regulation and both were noteworthy for the wide variation between predicted and observed values, a variation presumably attributable in large part to density-independent factors, such as those of physical oceanography. By and large, each species was treated as though it lived in isolation from other species. Indeed, each stock of each species was treated as distinct and separate, hence the term 'stock assessment'.

Oceanographers were a third solitude, focused on describing the physical circulation of the world's oceans, but increasingly adding appreciation of the chemical and biological processes of primary production and of the linkages through planktonic and benthic organisms to the fish community.

In still another solitude, a small number of economists considered questions such as how to maximize economic rent rather than sustained yield of biomass. A similar small group pursued the more general issue of social benefits.

The remaining solitudes were the fisheries managers and the fishing industry. For the most part, the management of marine fisheries in the 1950s through to the 1970s was more a matter of documenting the catch rather than controlling it. Distant-water fleets exploited virtually every comer of the world's oceans to within a few miles from shore. In those circumstances, national fisheries management was often frustrated and there was little incentive to constrain harvests by local fishers. In the developing world, especially, 
the operation of distant-water offshore trawlers coupled with the increasing numbers of people engaged in artisanal fisheries, put greater pressure on coastal fish resources for which traditional use rights and simple technologies had previously ensured sustainability.

Since those days, 25 to 35 years ago, great changes have taken place. The science of ecology has developed a 'substantial theoretical literature of ecosystem structure and function_Some major themes have been the significance of life history strategies to the structure of animal communities, the underlying mechanisms of population genetics, the patterns of energy flow and nutrient cycling, the complexity of community organization and the dynamics of community structure.

Major steps were taken in attracting the attention of ecologists to resource management and the attention of resource management specialists to ecology. A good example of the times was the text of Watt (1968). Subsequently, the work of Holling and his associalis (Holling. 1978) on adaptive environmental assessment and management underlined the value of alternating modelling with experiment in making resource management more of a hard science. The increasing volume of literature on control and optimization of dynamic systems was a great stimulus to analysis of the properties of ecological systems, especially those in which there was a harvesting component (Walters and Hilborn, 1978).

For single-species stock assessment, May et al. (1978) reviewed the properties of various stock-recruitment curves as they influenced the yield associated with various levels of effort in single-species Lotka-Volterra models. Their conclusion echoed the earlier work of Doubleday (1976) that unpredictable environmental variation leads to trade-offs between an average yield and a fluctuating yield, and their associated greater risks. Endless variations of the techniques of single-species stock assessment have been explored most recently with the use of Monte Carlo simulations, to evaluate the risks of overfishing given the uncertainties in the data (e.g. Smith et al., 1993).

The difficulties of addressing multispecies management have come increasingly to the fore and were reviewed extensively at a Dahlem workshop in Berlin (May, 1984) which was significant in reinforcing the trend of putting together groups that included binth ecologists and fisheries biologists. Significant progress has also been made in building bridges between oceanography and fisheries, and particularly in relating the success of year classes of commercially important species to oceanographic conditions (for example, Cushing and Walsh, 1976).

Oceanographers, meanwhile, aided not only by computing technologies but also by satellite imagery, made major advances in understanding the patterns of circulation of the world's oceans on a spectrum of scales of time and space (Mann and Lazier, 1991). Chemical oceanographers identified the linkages between physical circulation and nutrient recycling. Biological oceanographers focused on the reverberations in food chain linkages from changes in physical conditions (Steele, 1970).

Much attention has been given recently to what seem to be major changes in ocean climate and associated changes in abundance of various species. For example, warmer temperatures in the eastern North Pacific have been associated with major variations in abundance of several species of fishes (Beamish, 1993; Beamish and Bouillon, 1993). The catch of Pacific salmon (Oncorhynchus spp., Salmonidae) is at historically high levels. At the same time, changes in the oceanography in the Hawaiian archipelago have caused major shifts in numbers of sea birds and monk seals (Monacus schauinslandi, Phocidae) which may be traced to changes in the underlying trophic levels (Polovina, 
1994). In the Bering Sea and adjacent North Pacific, there have been significant declines in the numbers of some species of sea birds, and of Steller sea lions (Eumetopias jubatus, Otariidae) and harbour seals (Phoca vitulina, Phocidae), substantial increases in the abundance of several species of groundfish and wide variation in levels of recruitment of pollock (Theragra chalcogramma, Gadidae) and various species of crabs. Which of these effects are particularly or wholly attributable to the changes in oceanography in recent years is not resolved but it would be a very surprising if there was no connection.

The establishment of 200 mile exclusive economic zones was an important step in potentially rationalizing world fisheries, but in practice has not usually prevented continued exploitation. It follows, from the common property nature of fisheries resources, that they are vulnerable to exploitation, as has been abundantly demonstrat;:d by a succession of economists. The work of Clark summarizes various bio-economic scenarios that can lead to stock depletion (Clark, 1974) and which have been demonstrated in various fisheries over the past few decades. Recent research on fisheries economics has centred on 'rights-based fishing' (Neher et al., 1989), by which the common property may be divided into what amount to a number of pieces of private property in the form of rights to take a certain quantity of fish. New Zealand has led the way in implementing such a system in the form of individual transferable quotas (ITQs). The tendency for the quotas to become concentrated in a few hands has been noted as a social issue. Various countries, including Canada, Australia and Norway, have set individual quotas for some fisheries. Canada has set 'enterprise quotas' that assign quotas to processing plants. The TURF concept (territorial use and rights to fisheries), building upon traditional practices, encourages coastal communities to take over management of local resources and has been widely promoted, particularly in the developing world. Alaska has instituted community development quotas (CDQs) to foster the viability of coastal communities.

All these sorts of measures to restrict access to fisheries and to allocate the resource equitably have their good points and limitations, but the general trend to their adoption and development is much to be desired. There are many obstacles. Some people like fishing as a way of Iife and will vote for those who help them preserve it. In many parts of the world, fishing is seen as an occupation of last resort, something to keep people busy who might otherwise be a social burden. Most fisheries involve more than one type of gear, so there are endless squabbles about allocation of permissible catch. Some types of gear are far more effective but far more expensive so that only a few can afford them. Whole new dimensions of conflict and compromise are involved when stocks traverse international boundaries. These and many other considerations reinforce the status quo.

At least some of the difficulty in sorting out causes and effects in the fluctuations of fish populations has been the lack of reliability of the statistics of catch in many parts of the world. A significant proportion of the catch is discarded. With a limited amount of space in the hold, a fisherman will retain only what is worth retaining or what quotas or regulations allow. Fish of small size or Low-value species may constitute a substantial part of the catch, especially when the abundance of the target species has been reduced. The world marine catch could well be over $30 \%$ greater than the current estimate of 83 million tonnes per year (Alverson et al., 1994). That estimate does not include subsistence or recreational catches, fish killed but not caught by gear, ghost fishing by lost gear such as gill nets and traps, or landed catches that are rejected as unsuitable. 
Catch statistics also do not include fish that are landed but not reported, i.e. illegal fishing. Conversely, some fish reported as being landed are figments of the imagination of the reporter, and some are reported as the wrong species and not always because the reporter cannot tell the difference. Quite apart from these sins of omission and commission, the problems of collecting statistics can be very difficult in archipelagos such as Indonesia and the Phiiippines (Simpson, 1952). especially when there may be several hundred species in the catch. In brief, fisheries statistics are often unreliable as a precise indicator of fish abundance.

The difficulties of interpreting catch statistics have been confounded by rapid advances in the technologies of finding fish and catching them. Such a simple change as increasing the capacity of a vessel can provide a greater ability to exploit a local concentration of fish. Catch per unit of effort also changes with the experience of the fishermen. Even in the best of circumstances, catch statistics must be interpreted in the light of the changing capabilities of the fishing fleet. Despite their potential inadequacies. catch statistics are an indispensable tool of management and accordingly must be given highest priority.

To sunımarize, over the past 40 years, the science of fisheries management has become much more aware of and dependent upon the insights of ecology, oceanography. economics, sociology and political sciences. Maximum sustained yield (MSY) has given way to optimum sustained yield (OSY) (Larkin, 1977). Increasingly, the need has been recognized for the involvement of social scientists in the management of fisheries. This recognition has been the prelude to including humans as an integral part of the ecosysterns they exploit.

\section{Ecosystem management - what is it?}

In the Fisheries Management Section newsletter of the American Fisheries Society there is a one-lincr that neatly summarizes the present status of the term ecosystem management in the United States: 'The last I heard, high level administrators were looking for a definition for ecosystem management' (Schramm, 1994). Indeed, Bill S93 currently before the United States Senate proposes the establishment of an Ecosystem Management Commission whose first duty would be to develop a definition of the term ecosystem management!

Ecosystem management is shorthand for more holistic approaches to resource management. For example, Harden Jones (1994) provides an excellent summary of the evolution of the concept of ecosystem management from a natural sciences perspective. Quoting from ACMRR (1979) he states that ecosystem management implies 'the necessity of understanding multispecies interactions and questions of altered structure of the biological community (ecosystem stability). The management implications of the term 'ecosystem management' presume a reasonable understanding of the physical and chemical environment and the biological species which describe an ecosystem plus an understanding of the interactions among and between the species complex as well as thici environment'.

If humans arc taken to be one of the species of the ecosystem, father than ans an external influence, then the ecosystem can be envisaged as encompassing the full range of social, economic and political factors that influence human behaviour with respect to 
fisheries. Proponents of the concept do not generally go that far but nevertheless do add in the most relevant social, economic and political considerations. Thus, Sherman (1993) mentions that for LMEs, 'geographers, economists, government representatives, and lawyers' recognize the utility of the concept, that actions should be taken to mitigate pollution and habitat degradation, and that there are difficulties in management across international boundaries.'

Some of the contributors to Sherman et al. (1993) express reservations about the political practicality of managing LMEs. For example, Alexander (1993) points out some of the international jurisdictional problems and Prescott (1993) spells out the political complications on the west coast of Africa. Belsky (1993) analyses the six stages in the process of establishing a management system for an LME, each of which could be disrupted by political problems.

1. Gain scientific understanding and adequate statistics of catch.

2. Establish which countries are eligible to fish.

3. Obtain agreement among countries that each is to prepare a management plan.

4. Reconcile the management plans.

5. Get approval by governments of the comprehensive management plan.

6. Monitor the resources and if necessary, revise the plan.

Things become even more politically vulnerable when the concept of LME is coupled with the broader notion of 'ocean management' which takes in all uses of the ocean within the coastal zone. The idea is to exercise stewardship, maintain public safety. control interactions among uses and users and ensure an adequate return to the public from publicly owned resources (Knecht and Cicin-Sain, 1993). Everything that occurs in the coastal zone is included: oil and gas leasing, shipping, fisheries, pollution, coastal erosion, coastal development and any other uses or influencing factors. On an international scale the issues are multiplied.

All these kinds of concepts are reflections of legitimate concerns, but for operational purposes it is probably best to tackle them separately. Ocean management is an allembracing, comprehensive concept that has several components. One of those components is management of fisheries. Inevitably, there are economic, social and political factors that have direct bearing on fisheries management and which fisheries managers must deal with pragmatically, but the integration of all activities in areas where fishing occurs is far beyond the scope of ecosystem management.

Moreover, it is important to realize that the ecosystem as such is not in fact managed. There may come a day when it is possible to create upwelling wherever and whenever desired, and to control which species will constitute a food web, but for the foreseeable future those choices are only available to the fish culturist, who can manage a small ecosystem just as a farmer does, or to the manager of freshwater communities that are readily manipulated.

Ecosystem management thus has different connotations for ocean resources than for those based on land. Although the weather cannot be controlled for either, the manager has much more scope for intervention on land. Applied to marine ecosystems, the term ecosystem management is scientific shorthand for the contemporary appreciation that fisheries management must take greater note of the multispecies interactions in a 
community of fish species and their dependence on underlying ecosystem dynamics. If that appreciation must have a label, then ecosystem management has the advantage of being short and widely used, but it has unfortunately come to mean much more to many people. Apollonio's ( 1994) phrases 'ecosystem characteristics in fisheries management' and 'management based on ecosystem principles' have the merit of being less ambiguous.

From a biological perspective, for all ecosystems, whether on land or sea, an underlying principle of management is commonly assumed to be a sustained yield of products for human consumption and animal foods. Whether that should be taken to mean that the yield should always be of the same products is much less certain. For example, the prairies of western North America once produced large yields of bison but now produce cattle. Agriculture has fashioned its own ecosystem to manage. Much the same may be said of aquaculture. For fisheries on natural stocks, the first biological decision of fisheries management is whether the sustained yield is always to be of the same species in the same proportions_ In tropical fisheries where the number of species is large, it is to be expected that fishing will change the species composition (Jones. 1982) and indeed this has been observed to occur in many parts of the world (Larkin. 1952). The total yield may not necessarily decline, especially if gear becomes more diversified and the value of the catch may change. indeed it may transpire that after several years of high rates of exploitation in some tropical settings, the value may go up as yield goes down because of the greater quantities of shrimp in the catch (D. Pauly, pers. comm). Hence, fisheries managers, with the cooperation of local fishermen, were at one time clearing large hake (Merluccius merluccius, Merluccidae), chimaera (Hydrolagus affinis, Chimaeridae) and sharks from an area of Spanish coastal waters in the hope of creating a shrimp fishery (Sugihara, 1984).

The point remains that the biological objective of ecosystem management must specify the species mix that is desired in the yield and this may only be possible in general terms. What seems commonly to be assumed is that no species will be rendered extinct, the species composition will be kept the same, albeit with wide variations related to differences in year class strengths, and that a maximum sustainable yield will be profitably harvested from the multispecies mix. That is a goal that is much less achievable in the tropical zones than in temperate seas where there are fewer species and greater dominance of a few species. Greater importance can then be attached to the stock dynamics of the major actors. A somewhat similar view is expressed by Parrish. as quoted by Harden Jones (1994), who advocated that work on individual species should continue to provide the core activity for ecosystem management.

It seems likely that to limit the range of fluctuations in abundance of major species, fishing effort must be reduced. For most of the world's major coastal fisheries the available fishing capacity is well in excess, perhaps three or four times as much. as is necessary to take what is seen as the permissible harvest, even when the harvested stocks are at high levels of abundance Existing fleets are a blunt instrument for fine tuning the relative abundance of species. Moreover, they harvest, in greater or lesser degree, an associated bycatch which may be discarded another factor influencing the species mix of the ecosystem. Despite these problems, the objective of maintaining the full ensemble of species while sustaining a harvest of desired species has been tacitly accepted as a goal of management.

Grumbine (1994) lists five goals of what he calls ecosystem management. 
1. Maintain viable populations of all native species in situ.

2. Represent within protected areas, all native ecosystem types across their natural range.

3. Maintain evolutionary and ecological processes.

4. Manage over periods of time of sufficient duration to maintain evolutionary potential of species and ecosystems.

5. Accommodate human use and occupancy within these constraints.

The thrust of this set of goals comes from concerns for management of terrestrial ecosystems to which Grumbine's review as a forester was exclusively addressed. Whether they could ever be achieved for marine ecosystems is highly doubtful. Certainly it would be virtually impossible to know if all native species were being maintained at viable levels. Evolutionary and ecological processes will undoubtedly occur, but whether they can be directed is equally doubtful. Most to the point, virtually the only way to accommodate human use and occupancy would be for humans not to use or occupy the ecosystems. As goals they are idealistic and impractical.

Concern for the maintenance of global biodiversity has given rise to a large recent literature on threatened or endangered species. The pressures of world population, particularly in the developing countries, have, or will soon, render many land-based organisms extinct. Global concerns for biodiversity have been reflected in the adoption of a global convention at Nairobi in 1992 (Glowka et al., 1994).

For marine ecosystems, most major concerns have been expressed for marine mammals, sea birds and sea turtles. In recent years, attention has also been drawn to the depauperation of the fauna of coral reefs and the intensive search for species of high value such as giant clams (Tridacna spp., Tridacnidae) (Copland and Lucas, 1988) and the decline in species such as bluefin tuna (Thunnus saliens, Scombridae).

Generally speaking, it has not been considered likely that marine fish species could become endangered. Their distribution is wide and natural refuges abound. Once reduced to low numbers. it is uneconomic to fish for them, and in any event they can explode into abundance from very low levels (Myers et al., 1995). Whether these attitudes arc well founded has recently been questioned by Huntsman (1994), who suggests that at least 39 species of fish are severely depleted in United States territorial waters. He recommends the establishment of marine reserves as a prudent management measure. Tropical reef environments are especially vulnerable and the provision of marine reserves is an essential feature for sustainability of harvested stocks as well as protection for endangered species (Bohnsack. 1994; Russ and Alcala. 1994). Species that home to freshwater spawning areas such as salmon have distinctive adaptive racial characteristics. The loss of a race means the loss of a segment of a population. at least for several generations. The same may be true for many other species, whether or not they are anadromous.

Ecosystems contain large numbers of non-commercial species that may be affected regionally by top-down or bottom-up effects. For these species, many of which are virtually unknown and for which the only information available is their existence, the possibility is remote for knowing whether management has had any effect. For this very reason, the concepts of marine parks and sanctuary areas are obvious first steps in providing a measure of protection for at least the less widely ranging species until morc knowledge is available. 
Related to the current concepts of ecosystem management and biodiversity is a mushrooming literature on expressions such as 'ecosystem integrity' and 'ecosystem health' which, from a North American fisheries perspective, have been much used in discussion of the profound impacts of pollution, the introduction of exotics and the impacts of fishing on the Great Lakes (Bocking, 1994) and have led to the development of an 'Ecosystem Charter' for the Great Lakes-St Lawrence Basin (Hoffman, 1994). Kay and Schneider (1994) define ecological integrity as encompassing 'ecosystem health, the ability to maintain normal operations under normal environmental conditions', the ability 'to cope with environmental stress', and the ability 'to continue the process of selforganization on an ongoing basis'. Ecosystem health has been used to mean many sorts of things (Costanza et al., 1992) but is more or less a corollary of ecosystem integrity. Cailicott (1995). a professor of philosophy, envisages biodiversity and biological integrity as 'different from but not unrelated to, ecosystem health' and that 'Together these three normative concepts represent complementary conservation goals'. The expression 'ecosystem balance' also pops up and apparently stems from the romantic notion that in their natural state ecosystems are characterized by a stationary equilibrium (i.e. mother nature's balance), which is simply not true.

It is hard to come to terms with this sort of metaphorical language. Bocking (1994) points to 'Efforts to specify indicators of ecosystem integrity ... that integrate the impacts of anthropogenic stresses, and are meaningful to those who must participate in efforts to restore or maintain ecosystem integrity', thus bringing into the concept notions of public consultation as a part of decision making. Ecologists, in his words, 'are seen as contributors to a societal consensus on our comportment toward the environment. ... Thus, the concept of ecosystem integrity reflects a diminished confidence in the capacity of senior governments to impose solutions to environmental problems'.

This is the quasi-religious language of a social crusade. Translated into everyday objectives, it means that people want to be able to eat fish, see birds, swim at clean beaches, enjoy forests, breathe clean air - in short, to have an environment that has been well managed and to be heard when they speak up about it.

To summarize. ecosystem management for the marine environment has three essential components:

1. sustainable yield of products for human consumption and animal foods:

2. maintenance of biodiversity;

3. protection from the effects of pollution and habitat degradation.

These components must be reconciled with the social and economic costs involved and to a large extent their implementation will reflect the prevailing set of values. As John Gulland has said 'Everybody concerned with fishing will have slightly different ideas on what the proper objective of fishery management should be,' (Gulland, 1974). For some it may be as simple as maintenance of fishing communities and the employment they provide, an objective to be pursued regardless of the ecological consequences or the social costs. Others may see the maximization of economic rent as an ideal, employing only as few people as are necessary and using the most cost-effective technologies (Christy and Scott, 1965), also regardless of the ecological implications. Fisheries may also be seen as a bargaining chip in national or international politics. But none of these objectives should be confused with ecosystem management. 


\section{Some ecological models for marine ecosystem management}

The central biological question of marine ecosystem management is whether fishing activities or environmental factors are responsible for observed changes in abundance of fishes. Effects of fishing are called top-down effects because their impact is most commonly at the top of the food chain. Those concerned with effects of changes in the ocean environment are referred to as bottom-up effects because they influence the primary processes of production and take effect up through the food chain. In essence, the question of which is responsible is the same question that was posed 40 or more years ago about the roles of density-dependent or density-independent factors of population control.

Top-down theory was long dominated by variations of the Lotka-Volterra equations, which describe interactions between species in terms of who harms whom and who benefits from whom. Thus, predation is benefit for the predator, harm to the prey. Competition between species is mutual harm, but if the competitors do more harm to themselves than to each other then the two species may coexist. There are many variations on the theme. For example, Doi(1962), using an analogue computer. attempted to fit Lotka-Volterra equations to catches of various pairs of species in each of several prefectures in Japan. Larkin $(1963,1966)$ explored the consequences of exploitation on competing species and on predator-prey relations. May et al. (1979) comprehensively examined the implications for management of multispecies fisheries, reaching five conclusions, which may be paraphrased.

1. For populations at the top of the trophic ladder, the concept of maximum sustained yield (MSY) will often remain useful.

2. Other populations should not be depleted to such a level that their productivity or that of other species dependent on them is significantly reduced.

3. Monitoring should be set to the slowest population process time scale.

4. Harvesting levels should be set conservatively to safeguard against the combined effects of environmental variation and harvesting.

5. The intersections of these considerations with economic and political factors imply consequences and management implications that 'defy crisp summary'.

As devices for conceptualizing the consequences of various kinds of interactions, these kinds of equations are useful heuristic devices, especially when recast in discrete form for computer simulations which track the path to equilibria or extinction. But as devices for day-to-day management of fisheries they only provide general, rather commonsense, guidelines.

Casting the interactions in matrix form on the basis of food habits was suggested by Riffenburgh ( 1969) but was soon succeeded by computer simulation methodologies, which were pioneered by Andersen and Ursin (1977) for the North Sea and by Laevestu and Hayes (198 1) based on their modelling of the North-east Pacific Ocean ecosystem. Efforts of this kind, which seek verisimilitude with nature, are encumbered with a large number of parameters for which values cannot be gauged either precisely or independently.

Significant advances were made in modelling oceanographic ecosystems throughout 
the 1970s and 1980s (Nihoul, 1975; Fasham, 1984; Ulanowicz and Platt, 1985; Wulff et al., 1989) and continue to the present day. One of the more comprehensive models is a steady-state representation of aquatic ecosystems called ECOPATH, originally developed by Polovina (1984) and subsequently modified by Christensen and Pauly (1992) using some of the analytical methods of Ulanowicz (1986). The result, called ECOPATH II, is a methodology for describing in quantitative terms the energy flows through the various trophic levels of an ecosystem. The methodology is evolving rapidly and has incorporated a method developed by Ulanowicz and Puccia (1990) to quantify direct and indirect interactions in a fashion similar to an input/output matrix. ECOPATH analyses of 41 freshwater and marine ecosystems are presented in Christensen and Pauly (1993a), together with a summary commentary (Christensen and Pauly, 1993b) and an outline of the principal features of the methodology (Christensen and Pauly, 1993c).

ECOPATH is a diagnostic tool for identifying gaps in understanding of aquatic ecosystems and a potential predictor of the gross impacts of large-scale exploitation. Its limitation is that of all steady-state models in not depicting temporal and spatial dynamics. New models that overcome this shortcoming are said to be on the way (Olivieri et al.. 1993). A further limitation is the lack of specific information on which to structure the depiction of the ecosystem. In consequence an ECOPATH mode1 may of necessity be built on several assumptions based on general ecological principles rather than on independently measured parameters.

Much of the theory of top-down an bottom-up effects has been developed in freshwater environments, which differ from marine settings in being more geographically confined and more subject to the influence of human activities other than fishing. A history of the ecosystem concept in freshwater settings and the contrast with marine ecosystems is given in the excellent review by Magnuson (1991). in the past few decades, many studies have been undertaken on grazing, competition and predation as major top-down interactions in determining the structure of freshwater communities, and on which nutrients limit primary production with ramifications upward through the food chain as bottom-up effects. These two lines of enquiry are brought together in the trophic cascade hypothesis, which postulates that nutrient input sets the potential productivity and that deviations from the potential are the consequence of food web effects (Carpenter et al., 1985). Not all of the cascading effects are directly linked to food webs (Kerfoot, 1987).

Models for trophic cascades are not completely successful for prediction to the species level of the consequences of manipulation (Carpenter and Kitchell,1993), but predictions of a more genera1 nature are borne out with fair consistency. For example, biomasses at adjacent trophic levels are expected to be inversely related. It follows that biomasses at trophic levels separated by an intermediate level will be directly related. Thus, as an oversimplified example, an increase in the number of predators may decrease the numbers of zooplankton feeders which may result in an increase in the biomass of zooplankton which in turn may cause a decrease in phytoplankton which may influence the relative importance of nitrogen and phosphorus as limiting factors for phytoplankion production. The size of the organisms at different trophic levels substantially influences the outcome of a top-down effect. Perturbations of species that interact strongly with other species (keystone species) are likely to yield trophic cascades (Paine, 1980). Most to the point of marine fisheries management, a predator with a broad diet may be capable of regulating an entire ecosystem component and cause a trophic cascade. Local 
extinction of prey by generalist predators is quite common in freshwater systems, particularly if the predator is relatively long lived (Murdoch and Bence,1987), but switching to alternative prey is perhaps the more common expectation.

Some of these sorts of phenomena have been observed in marine ecosystems. The much-studied Peruvian upwelling ecosystem is characterized by episodic El Niiio events that warm coastal waters, with a resultant decrease in nutrient supply from upwelling that is reflected throughout the food chain. Zooplankton abundance is reduced, anchoveta (Engraulis ringens, Engrauiidae) numbers decline, but sardines (Sardinops sagax, Clupeidae), horse mackerel (Trachurus picturatus murphyi, Carangidae) and mackerel (Scomber japonicus, Scombridae) increase in abundance and guano birds (Phalacrocovar bougainvillii, Phalacrocoracidae, Sula variegata, Sulidae. and Pelecanus thagus, Peiecanidae) and fur seals (Arctocephalus australis, Otariidae) decline in numbers (Pauiy et al., 1989). When intense fishing is coupled with ElNiño events the stock of anchoveta is depressed to such low levels as to prevent recovery. Exploitation of horse mackerel has been suggested as an alternative (Muck, 1989).

In addition to the effects of overfishing, eutrophication and pollution, the Black Sea has been virtually taken over by ctenophores (Mnemiopsis leidyi, Bolinopsidae) introduced from somewhere on the coast of the Americas in ship ballast. These jellyfish-like creatures now constitute a large proportion of the macroscopic biomass and are heavy predators on zooplankton, small crustaceans and the eggs and larvae of fish (Travis, 1993). Long-term changes in the composition of bottom fish catches in the western Bering Sea and along the coasts of Kamchatka and the Kuriles have been attributed to both the direct effect of fishing and its mediated effect through food chains (Il'inskii, 1991). In the eastern Bering Sea, also, there have been changes in relative abundance of some species (for example, king crab (Paralithodes camtschaticu, Lithodidae), Greenland turbot (Reinhardtius hippoglossoides, Pleuronectidae), blacklegged kittiwakes (Rissa tridactyla, Laridae)) but the evidence as to the causes is not clear cut (Livingston et al., 1994). Many more examples can be drawn from various parts of the world.

Changes in many marine ecosystems have no doubt occurred, but efforts to model their holistic dynamics have not yet been successful. The various subsystems can be modeiled with some success, such as the relation between nutrient levels and phytoplankton abundance, or the grazing of zooplankton on phytoplankton, or the fecding of rishon zooplankton, but putting the various subsystems together in the context of temporal and spatial variation has proved to be intractable. The difficulty lies partly in the number of variables and the way in which only small errors in their estimation may lead to large effects in the simulated result. Compounding the problem is the lack of data for all trophic levels and all scales of time and place. For most ecosystems, there are insufficient historic data to provide some indication of the natural range of variability (Schindler, 1987). A further complication is that many species of fish move from one trophic level to another as they grow larger. It is also common for some species to move further offshore as they age. Realistically, for some time to come, ecosystem models will not be successful in predicting individual species variations in abundance. But what they can provide is a depiction of the interdependencies between trophic levels, which may serve at least as gross indicators of major modifications.

A somewhat similar conclusion was reached by Austen et al. (1994) in advocating that the combined abundance of ail species in a guild (i.e. species that exploit the same class 
of resources in a similar way) might more accurately reflect changes in resources or limiting factors. The relative abundance of species within a guild might change if only some species are harvested. An approach of this kind is taken by Livingston et al. (1994) in depicting eastern Bering Sea ecosystem trends.

Wilson et al. (1991) present a model based on 'community predation' which acknowledges the tendency for big fish to eat small fish of almost any species. The resulting model generates chaotic behaviour of individual populations but stability of the entire system, an interesting but not very useful conclusion.

At present, the state of the art in detecting ecosystem change is centred on choosing some species or characteristics as indicators. For example, on the Great Lakes, lake trout (Salvelinus numavcush. Salmonidae) have been proposed for indicator status because of their vulnerability to a variety of factors. Schindler (1990) concluded that the most sensitive indicators of ecosystem change were characteristics such as species diversity, the number of links in a food chain, the proportion of opportunistic species with high rates of increase (so called $r$ species, an inheritance from Lotka-Volterra) and changes in the average size and life span of species. The gross variables of ecosystems, such as respiration or total production, are quite insensitive, to the extent that once they arc changed the ecosystem has been irreversibly modified.

The close collaboration of oceanographers, ocean ecologists and fisheries biologists in ecosystem modelling holds promise for long-term understanding but in the short term is unlikely to inspire substantial changes in management tactics. The absence of long-term time series of data over large areas is alone sufficient to engender pessimism, but even given the data, modelling of whole ecosystems may not shed much light on changes in abundance of individual species.

Even the long-term relevance of ecosystem understandings to fisheries management may prove to be elusive. The Island Institute conference on applying ecosystem principles to marine fisheries gives a vivid contrast between the kinds of generalities that can come from ccology and the kinds of issues that face fisheries managers (Platt, 1993). It is the difference between theorists and practitioners, between strategies and tactics, between observers and participants. The summary list of 20 systems properties that emerged from the discussions is an excellent synopsis of the broad relevance of ecology to fisheries management, but contains nothing of immediate value to fisheries managers. Perhaps the next generation of ecosystem modellers, armed to the teeth with computing savoir faire, will move understanding closer to the action, but meanwhile there is not much there to apply.

A conspicuous exception to this pessimistic point of view may be the International Convention for the Conservation of Antarctic Marine Living Resources (CCAMLR), which specifically advocates a holistic ecological approach in management of the relatively simple Antarctic community of marine birds, marine mammals and exploited stocks of krill and fishes. Although the convention has yet to demonstrate full understanding of the dynamics of the ecosystem, it has raised awareness of the interdependency of its various components. Knox (1994) provides a comprehensive account of the current state of knowledge of the Antarctic Ocean and of alternative management strategies.

For most marine ecosystems, even given the necessary ecological understanding, the costs of acquiring the necessary data may prohibit highly sophisticated forms of management. Increases in expenditures on management are likely to be associated with 
lesser risks of mismanagement but with diminishing increases in yield, so that it may be cheaper to take smaller harvests than to strive for maximum aggregate sustainable yields.

Moreover, as is the case for environmental contaminants, deciding on acceptable risks in management may involve weighting of many factors (Mount, 1992) which should be clearly communicated to all concerned (Conn and Rich, 1992). In all likelihood, with present levels of understanding of the complexities of marine ecosystems, assessments of risk will not always be precise, and there is always the risk of crying wolf (Tullock and Brady, 1992).

\section{Practical models for marine ecosystem management}

Aware of the shortcomings of ecosystem modelling ('Ecological research has not truly erupted with practical answers'), McGlade (1989) presented a different approach termed integrated fisheries management (IFM). Models built on this concept stress the interaction between the fish resources, the fishing industry and institutional structures. The performance of resource management systems 'is assessed in terms of goals, systematic structures and institutional constraints' asking questions such as 'To what degree do conflicting goals jeopardize management success?', 'To what degree does institutional weakness determine management performance?' and 'Can legal frameworks and institutions be corrected in sufficient time to avoid stock collapse?'

The IFM approach is not unaware of the ecological basis of fish production, but focuses instead on what can be done with the human system with which it immediately interacts. Fishers and fish processors trade fish for money according to some social, economic and political rules. The IFM approach focuses equally on the fish and money sides of the transaction and what regulators can do about it.

The integrated fisheries management (IFM) approach has the great merit of dealing with the fishing industry as a sophisticated, highly adaptable super predator, the properties of which must be known before they can be managed. The best way of ensuring progress is by involving the industry in studying itself. As is now becoming widely accepted, participatory research is often the best way of ensuring acceptance and implementation of research findings, a truism with special relevance to fishing. In many parts of the world the fishing industry is its own worst enemy, and that will not change until a community sense of responsibility takes precedence over the imperatives of self interest. By becoming active participants in collaborative management and research with government, industry has much to gain. Of course there are issues concerning free enterprise, and the evils of the present system should not be exchanged for a mind set that could be associated with centralized planning. (For an interesting commentary see Nikitina and Pearse (1992) on changes in the former USSR.)

An example of a simple kind of IFM is provided by Overholtz et al. (1993), who examined strategies for rebuilding and harvesting New England groundfish resources. Coupling stock assessment and economic models enabled evaluation of net economic benefits of reducing effort.

In a somewhat similar vein, several attempts have been made to model the way in which the fishing fleet interacts with multispecies assemblages of fish species (Murawski, 1984; Pikitch, 1987, 1991; Boyle et al., 1991; Laurec et al., 1991; Murawski et al., 1991). Sharp attention is drawn to the ways in which fishing operations 
and technologies and their economics adjust to fishing regulations and to relative prices for various species, in short to the behaviour patterns of fishers as super predators. Long the realm of anecdotes, this is an area of study much in need of attention.

An inherent assumption of these types of approach is that the species being examined are major actors in the system and, except for dependence on oceanographic conditions for recruitment. are able to adapt to changes in the relative abundance of other species. Bearing in mind that these were the characteristics that made them dominant in the first place, there is every reason to expect them to stay that way. Capable of recovery, given a sufficient stock of spawners to capitalize on favourable conditions for recruitment. dominant species can be managed as single species. This is the conclusion of Parrish (1979) as quoted by Harden Jones (1994), with which I concur. Moreover, as McGlade (1989) argues, from the fishing industry point of view, the harvestable species that move in to any temporary vacuum may be of far greater importance to fishing fleets than the understanding of what is going on at lower trophic levels.

These approaches all have the merit of including industry considerations in assessments, but they may gloss over the difficulties of obtaining the necessary proprietary information -and tracking the national and international operations and transactions of the fishing industry (the invisible hand of commerce). The logic of political decisions may also defy modelling.

A variety of multispecies models have been built on designs similar to those of singlespecies models to address the various interactions among the species of fish in a fishery. Predation mortality and fishing mortality, and in some instances their effects on growth and recruitment, are incorporated in a multispecies stock assessment. The outputs of multispecies virtual population analysis (MSVPA) are estimates of fishing and predation mortalities, suitability coefficients (i.e. the relative importance as food for predators) and stock numbers. The ICES multispecies assessment working group has used these sorts of techniques for many years in assessing the status of North Sea stocks, building upon what was originally one of the core components of the Andersen and Ursin (1977) model (Pope, I99 1). The contemporary status of this genus of modelling is summarized by Sparre (199 1). The advantage of MSVPA is its emphasis on the major interacting elements in the fish community. The weakness is the reliance on fisheries statistics. which in many parts of the world are inadequate, and on data on the diet of the various species concerned, which may be even less adequate.

In an overview of MSVPA, Sissenwine and Daan (1991) identify some of the areas of research that will lead to further development and conclude that the methodology has a promising future. Combining MSVPA and fleet interaction models seems to be a particularly promising approach (Brugge and Holden, 199 1).

From the perspective of IFM and MSVPA modelling, the issue of bycatch takes on a somewhat different light. Bycatches that are of species in the same trophic guild may reduce competition with favoured species. Of course, it is desirable from a 'waste not. want not' ethic to retain all of the bycatch, but it is not an ecological imperative (you do not have to eat weeds you pull from your garden). The reduction of bycatch to reduce user group conflicts, or to prevent mortality of endangered species is desirable, but 'thinning' (i.e. the discard of competing species of low value, or also perhaps of juveniles of desired species) may make sense to fishers or processors and at the same time could be a sensible fisheries management practice. The notion of considering some of the bycatch as trash fish to be thinned out to make way for more valuable species is not 
prominent in current thinking about bycatch issues. The contribution of the discards to scavengers may also have implications for relative abundance of various species, ranging from seagulls to shrimps and sharks.

A novel and direct experimental approach to multispecies management in tropical waters. focusing on the feedback between management action and empirical learning about resource dynamics, has been developed for the north-west shelf fisheries of Australia (Sainsbury, 1984, 199 1). An outstanding example of adaptive management, the method has the limitation of requiring at least five-year management periods to allow 'sufficient resolution of uncertainties', but it may well be the only realistic way of dealing with the great complexity of tropical fish communities.

Regardless of which approach is taken to fisheries management, the need to reduce fishing capacity is commonly taken as a first essential. Where parties differ is in the means by which capacity is to be reduced. The transferable quota approach can lead to high grading of the catch as well as concentration of quotas in a few hands. Unless quotas are expressed as proportions of a total allowable catch, there is little incentive for long-term conservation. Increasing of licence fees has the great merit of forcing economic efficiency but can exclude the smaller operator. Buy-out programmes and tieup schemes tend to remove the least effective at a relatively high cost. Fractional licensing has been proposed as an approach for the Hawaii longline fleet (Townsend and Pooley, 19941. In the developing world considerable attention has been given to the concept of local management responsibility, giving local residents a sense of ownership in the resource. In the face of growing populations and demands for jobs, the phasing down of fishing capacity is not easy, but without it the future of fisheries resources looks dim in many parts of the world. For all schemes involving reduction in fishing capacity, the age structure of the fishing fleet is a useful bit of information that is often lacking (Caddy, 1993).

The Gulf of Alaska and the eastern Bering Sea provide a particularly good opportunity for progressive management of a major world fisheries resource currently yielding a total annual catch approximating 3.5 million tonnes. The regulatory agencies for Alaska fisheries are certainly aware of the challenges of ecosystem management. With the signing of the International North Pacific Fisheries Treaty in 1954, an era of close collaboration between the United States, Japan and Canada facilitated exchanges of scientific and statistical information. The subsequent inclusion of the former USSR as a treaty signatory further enhanced the statistical data base. Some gaps in the data record persist, particularly concerning catches by other nations in the years prior to the declaration of 200 mile zones, but for recent years the data base on fisheries is at least as good as, if not better than, that for other well-documented fisheries in the world. Stock assessments are at state-of-the-art level.

An awareness of ecological factors characterizes debate about reasons for such changes as the decline in king crab populations, fluctuations in the recruitment of pollock, decline in Steller sea lion numbers, and the phenomenal performance of Bristol Bay sockeye salmon (Oncorhynchus nerka) stocks (e.g. Wooster, 1993).

The North Pacific Fisheries Management Council (NPFMC) plan teams for the groundfish fisheries of the Bering Sea, Aleutian Islands and Gulf of Alaska (1994) propose that the primary ecosystem management goal should be set as 'the maintenance of Alaskan marine biodiversity at the average level observed over the past 100 years'. Ecosystem components for 'special emphasis' would include 'seabirds, marine mammals, 
fish and other taxa that could be depleted to threatened/endangered status as a result of fishing'. The main goal of ecosystem management is said to be 'to ensure that human activities do not significantly alter the natural course of ecosystem dynamics'. These are broadly stated and general goals, but they reflect a general awareness of ecosystem perspectives.

This awareness stems from the realization that the fisheries of the region may be approaching a stage of development that requires more intensive and perhaps more conservative management if present high values of the fisheries are to be maintained, within the constraints of endangering particular species. That kind of management can only come from greater investments in research, particularly by the National Marine Fisheries Service and the Alaska Department of Fish and Game, and the active involvement of industry in examining the economic implications of various scenarios of regulation.

The other essential is a clear statement of objectives of management in Ianguage other than that designed to justify whatever was, is or will be decided. Despite various speculations about the causes of trends in the relative abundance of various species (some groundfish for example). there does not seem to be judgement about whether the trends coincided either with objectives or predictions. Thus, management seems to be reactive rather than proactive, which is perhaps satisfactory from a conservation perspective, but is fairly typical passive ecosystem management, perhaps stemming in large part from the extensive consultation with users that is the practice of the NPMFS.

Reconciling ecosystem management with the economic and social realities of the many user groups is never easy.

\section{Concluding comment}

Leaving aside questions of protection of the resource from pollution and habitat degradation, management of marine ecosystems, or more properly, management of marine fisheries with awareness of ecosystem properties, is essentially a question of distinguishing the impacts of fishing from those of fluctuations in the ocean environment. understanding the dynamics of species interactions and appreciating the way in which fishing fleets will respond to changes in the abundance of various stocks of fishes, ail with the objective of achieving sustainable yields. One of the morals is to ease up on fishing when environmental conditions are unfavourable. A common feature of many collapses in fish stocks is the combination of top-down and bottom-up effects that ensues from continued heavy fishing after a series of recruitment failures caused by adverse environmental conditions. Collie and Spencer (1993) demonstrate how fishing can thus hasten the collapse and prolong the recovery of a fishery. It is not simply a matter of top-down or bottom-up, but rather of top-down and/or bottom-up.

Whether it is realistic at the same time to provide for biodiversity depends in part on how much special protection is to be afforded to which species. Marine mammals and sea birds, for example, are given high priority for special protection, but like fishing, they too may have significant roles in shaping the structure of marine ecosystems, together consuming an amount equal to that of the human catch in many ecosystems (Bax, 1991; Overholtz et al., 1991). Seals, sea lions and other pinnipeds are generalist predators at uppermost trophic levels and can influence the relative abundance of fish 
species. The consumption of krill by whales may reduce the production of fish and birds that feed on krill. Sea otters (Enhydra lutis, Mustelidae) are notorious for their top-down impact on near-shore invertebrate communities. Thus, full protection for all marine mammals will have substantial effects on the ecosystem structure that may or may not be compatible with human interests in fish as food. Eventually, ecosystem management must come to grips with the question of how much protection of particular species is desirable in achieving optimal use of living marine resources.

Discussion of the meanings of ecosystem management, whether with reference to landbased or to marine resources, is currently fashionable and is often conducted in the context of concerns for the world as an ecosystem. Climate change induced by grccnhousc gases. ultraviolet radiation and the ozone hole, pollution, world population, losses of arable land, disappearing forests, apprehended shortages of various commodities and other such topics are commonplace areas of comment. Coupled with the message that society must change from a consumer to a conserver philosophy, powerful arguments can be made for sweeping social changes that hinge on treating humans as a driving force in globai ecosystem dynamics.

But it is important not to confuse those discussions with ecosystem management. which is only one strand in a more comprehensive fabric. Ecosystem management is essentially the province of ecologists and professional resource managers, who draw on a long experience. The need to distinguish between environmentalists and ecologists is increasingly to the fore (Gee, 1995). Perhaps even more important is the distinction between environmentalists and resource managers. Their roles should not be confused.

This review began with a quotation from Egolfs Bakuzis of the University of Minnesota School of Forestry. it is perhaps appropriate to close on a quotation from a representative of the current generation of foresters, J.P. Kimmins of the University of British Columbia. Faculty of Forestry. Kimmins (I 99 la, 199 l b, 1993) has devoted much of his energies in recent years to trying to come to grips with the concept of 'sustainable development', the legacy of the Brundtland Commission. Observing what seems to be the 'inexorable growth' in human populations and the deterioration of the global environment, deploring the oversimplifications of the 'green religion', emphasizing the necessity for informed technical and scientific understanding and recognizing the social, economic and political contexts of society, Kimmins writes 'The challenge is to decide at what spatial and temporal scales we will evaluate sustainability. what balance of values is to be sustained in any particular forest, and what patterns of variation in values over time are consistent with the concept of sustainability'. Much the same may be said for fisheries.

\section{Acknowledgements}

This review was prepared with a grant from the Ocean Trust through the efforts of Thor Lassen to whom I am grateful. John Roos, D. Lee Alverson and John G. Peterson made useful comments on an initial version. The extensive comments of three anonymous external reviewers were most helpful. Pamela Rosenbaum prepared the manuscript for publication, made many trips to the library and in many other ways was invaluable as an assistant. 
References

AC.MRR ( 1979) Interim Report of the ACMRR working party on the scientific basis for determining management measures. Rome 6-13 December. 1978. FAO Fish. Circ. No. 718. $112 \mathrm{pp}$.

Alexander. L.M. ( 1993) Regional approach to large marine ecosystems. In Sherman, K.. Alexander. L..M. and Cold. B.D. eds. Large Marine Ecosystems V: Stress. Mitigation and Sustainability. Washington, DC: AAAs Press. pp. 225-6.

Alverson. D.L. and Larkin. PA. ( 1993) Fisheries: fisheries science and management: century 21. In Vorgtlander, C.W.. ed. Proc. World Fisheries Congress. Athens, Greece, May 3-8, 1992. New Delhi: Oxford \& I.B.H.. pp. 150-67.

Alverson. D.L.. Freeberg. M.H.. Murawski. S.A. and Pope. J.G. (1994) A global assessment of fisheries bycatch and discards. FAO Fish. tech. Pup. No. 339. 233 pp.

Andersen. K.P. and Lirsin. E. (1977) A multispecies extension to the Beverton and Holt theory of fishing, with accounts of phosphorus circulation and primary production. Meddr KommmDanm. Fisk.og Havunders. (N.S.) 7, 3 19-435.

Apoilonio. S. (1994) The use of ecosystem characteristics in fisheries management. Rev. Fish. Sci. 2. $157-80$.

Austen. D.J., Bayley. P.B. and Menzel. B.W. (1994) Importance of the guild concept to fisheries research and management. Fisheries 19(6),12-19.

Bakuzis. E.V. (1969) Forestry viewed in an ecosystem perspective. In Van Dyne, G.M., ed. The Ecosissem Concept in Vatural Resource Management. New York: Academic Press. pp. 189-258.

Bax. N.J. (1991) A comparison of the fish biomass flow to fish, fisheries and mammals in six marine ecosystems. ICES mar Sci. Symp. 193, 217-24.

Beamish. R.J. (1993) Climate and exceptional fish production off the West coast of North America. Cun. J. Fish. acfuat. Sci. 50, 2270-91.

Beamish. R.J. and Bouillon. D.R. ( 19933 Pacific saimon trends in relation to climate. Can. J. Fish. suquat. Sci. 50. 1002-I 6.

Belsky, M.H. (1993) Legal requirements for management of large marine ecosystems and their component resources. In Sherman, K., Alexander, L.M. and Gold. B.D., eds. Lurge Marine Ecoststems V: Stress. Mirigation and Sustainability. Washington, DC: AAAs Press. pp. 227-36.

Beverton. R.J.H. and Holt. S.J. (1957) On the Dynamics of Exploited Fish Populations (Min. Ag. Fish. Food. Fishery Investigations, Series II, Vol. XIX). London: HM Stationery Office. 533 pp.

Bocking. S. (1994) Visions of nature and society, a history of the ecosystem concept. Alternatives 20(3). 12-16.

Bohnsack. J.A. (1994) Marine reserves: they enhance fisheries, reduce conflicts, and protect resources. VAGA. the ICLARM Quarterly (July). 4-7.

Boyle. R.N.. Sinclair. A.F. and Hurley,P.C.F. (1991) A bioeconomic model of an age-structured groundfish resource exploited by a multi-gear fishing fleet. ICES mar. Sci.Symp. 193. 264-74.

Brugge. W.J. and Holden, M.J. (1991) Multispecies management: a manager's point of view. ICES mar. Sci. Symp. 193, 353-S.

Caddy. J.F. (1993) The age structure of fishing fleets and its relevance for reconstructing past fishery trends and forecasting. In Kruse, G.. Eggers, D.M., Marasco. R.J., Pautzke. C. and Quinn. T.J. II eds. Management Strutegies for Exploited Fish Populations. Fairbanks: University of Alaska, Alaska Sea Grant College Program Report 93-02, pp. 475-92.

Caliicott, J.B. (1995) A review of some problems with the concept of ecosystem health. Ecosistem Health 1(2),101-12.

Carpenter, S.R. and Kitchell, J.F. (1993) The Trophic Cascade in Lakes. Cambridge: Cambridge Univ. Press. 385 pp.

Carpenter. S.R.. Kitchell, J.F. and Hodgson. J.R. (1985) Cascading trophic interactions and lake productivity. Bioscience 35, 634-9.

Christensen, V. and Pauly, D. ( 1992) ECOPATH II - A system for balancing steady-state ecosystem models and calculating network characteristics. Ecol.Modelling 61, 169-85. 
Christensen, V. and Pauly, D. (eds) (1993a). Trophic Models of Aquatic Ecosystems (ICLARM Conf. Proc. 26). Manila: ICLARM.

Christensen, V. and Pauiy, D. (1993b) Flow characteristics of aquatic ecosystems. In Christensen, V. and Pauiy. D. eds. Trophic Models of Aquatic Ecosystems (ICLARM Conf. Proc. 26). Manila: ICLARM. pp. 338-52.

Christensen, V. and Pauly. D. (1993c). On steady-state modelling of ecosystems. In Christensen. V. and Pauly, D. eds. Trophic Models of Aquatic Ecosystems (ICLARM Conf. Proc. 26). Manila: ICLARM. pp. 14-28.

Christy. F. and Scott. A.D. (1965) The Commonwealth in Ocean Fisheries: Some Problems of Growth and Economic Allocution. Baltimore. MD: Johns Hopkins University Press. $281 \mathrm{pp}$.

Clark, C. W. (1974) Mathematical Bioeconomics: The Optimal Management of Marine Resources. New York: John Wiley and Sons. $352 \mathrm{pp}$.

Collie. J.S. and Spencer. P.D. (1993) Management strategies for fish populations subject to long-term environmental variability and depensatory predation. In Kruse, G.. Eggers, D.M.. Marasco, R.J.. Pautzke. C. and Quinn, T.J. II, eds. Management Strategies for Exploited Fish Populations. Fairbanks: University of Alaska, Alaska Sea Grant College Program Report 93-02. pp. 629-50.

Conn. W.D. and Rich. R.C. (1992) Communicating about ecosystem risks. Adv. mod. env. Toxicol. 20, I-8.

Copland, J.W. and Lucas, J.S. (1988) Giant Clams in Asia and the Pacific (ACIAR Monograph No. 9). Burwood. Australia: Crafterman. 274 pp.

Costanza. R.. Norton, B.G. and Haskell, B.D. (eds) (1992) Ecosystem Health: Vew Goals for Environmental Management. Island Press.

Cushing. D.H. and Walsh. J.J. (1976) The Ecology of the Seas. London: Blackwell. $467 \mathrm{pp}$.

Doi, T. (1962) [On the predatory and competitive relationships among fishes caught in the waters adjacent to Japan]. Bull.Tokai Regional Fish. Res. Lab. 32, 49-l 18 [Transl. Fish. Res. Bd. Canada No. 461].

Doubleday, W.G. ( 1976) Environmental fluctuations and fisheries management. Int.Comm. Northw: Atlant. Fish. Sel. Pup. 1, 141-50.

Fasham, M.J.R. ( 1984) Flows of Energy and Materials in Marine Ecosystems. London: Plenum.

Gee. H. ( 1995) American ecology at the crossroads. Nature 375, 461.

Glowka. L.. Buchenne-Guiimin, F. and Synge, H., in collaboration with McNeely, J.A. and Gündling. L. (1994) A Guide to the Convention on Biological Diversity. (Environmental Policy and Law Paper No. 30) IUCN.192 pp.

Grumbine. K.E. (1994) What is ecosystem management? Conserv. Biol. 8. 27-38.

Gulland. J.A. (1974) The Management of Marine Fisheries. Seattle: University of Washington Press. $198 \mathrm{pp}$.

Harden Jones. F.R. (1994) Fisheries Ecologically Sustainahle Development: Terms and Concepts. Hobart. Tasmania: IASOS, University of Tasmania. 205 pp.

Hoffman. J.K. ( 1994) Ecosystem Charter a vision for the future. Great Lakes Commission SemiAnnual Meeting Highlights. p. 2.

Holling. C.S. (ed.) ( 1978) Adaptive Environmental Assessment and Management. New York: John Wiley \& Sons. 363 pp.

Huntsman. G.R. ( 1994) Endangered marine finfish: neglected resources or beasts of fiction? Fisheries 19(7). S-IS.

II'inskii. E.N. (1991) Long-term changes in the composition of bottom fish catches on the continental slope in the western part of the Bering Sea. along the Pacific seaboard of Kamchatka and the Kurils. Lionersi ikhiologii $31(1) .73-81$

Jones. R. (1982) Ecosystems. food chains and fish yields. In Pauly. D. and Murphy, G.I.. eds. Theory and Management of Tropical Fisheries (ICLARM Conf. Proc. 9). Manila: ICLARM and Cronulla: Fisheries Division. CSIRO. pp. 195-237.

Kay. J.J. and Schneider, E. (1994) Embracing complexity. The challenge of the ecosystem approach. 
Alternatives 20. 32-9.

Kerfoot. W.C. (1987) Cascading effects and indirect pathways. In Kerfoot. K.C. and Sih, A., eds. Predation: Direct and Indirect Impacts on Aquatic Communities. Hanover and London: University Press of New England. pp. 57-70.

Kimmins, J.P.(Hamish)(199la\$) The future of the forested landscapes of Canada. Forestry Chron. 67, $14-18$.

Kimmins, J.P. (Hamish) (199lb\$) Sustainable forestry: can we use and sustain our forests. Edmonton: University of Alberta, Forest Industry Lecture Series 27. 16 pp.

Kimmins, J.P. (Hamish) (1993) Ecology, environmentalism and green religion. Forestry Chron. 69, 285-9.

Knecht. R.W. and Cicin-Sain. R. (1993) Ocean management and the large marine ecosystem concept: taking the next step. In Sherman. K., Alexander, L.M. and Gold, B.D., eds. Large Marine Ecosystems V: Stress. Mitigation and Sustainability. Washington. DC: AAAs Press, pp. 237-41.

Knox. G.A. (1994) The Biology of the Southern Ocean. Cambridge: Cambridge University Press. 444 pp.

Laevestu, T. and Hayes, M. L. (198 I) Fisheries Oceanography and Ecology Farnham. Surrey: Fishing News Books.

Larkin. PA. (1963) Interspecific competition and exploitation. J. Fish. Res. Bd Can. 20. 647-78.

Larkin. P.A. (1966) Exploitation in a type of predator-prey relationship. J. Fish. Res. Bd Can. 23. 349-56.

Larkin.P.A. (1977) An epitaph for the concept of maximum sustained yield. Detroit 1976. Trans.Am. Fish. Soc.106, I-I 1 .

Larkin. P.A. (1982) Directions for future research in tropical multispecies fisheries. In Pauly, D. and Murphy, G.I., eds. Theory and Management of 'Tropical Fisheries (ICLARM Conf. Proc. 9). Manila: ICLARM and Cronulla: Fisheries Division. CSIRO, pp. 309-28.

Laurec. A., Biseau. A. and Charuau, A. (1991) Modelling technical interactions. ICES mar. Symp. 193, 225-36.

Livingston, P.A., Low, L.L. and Marasco, R.J. (1994) Eastern Bering Sea ecosystem trends. Seattle: NMFS, Alaska Fisheries Science Center. 14 pp. +19 figs.

McGlade. J.M. ( 1989) integrated fisheries management models: understanding the limits to marine resource exploitation. In Edwards. E.F. and Megrey, B.A., eds. Mathematical Analvsis of Fish Stock Dynanics. Bethesda, MD: Am. Fish. Soc., pp. 139-65.

Magnuson, J.J. (1991) Fish and fisheries ecology. Ecol. Appl.1(1), 13-26.

Mann, K.H. and Lazier, J.R.N. ( 199 I) Dynamics of Morine Ecosystems. Biological-physicul Interactions in the Oceans. Oxford: Blackwell. $466 \mathrm{pp}$.

May, R.M. (1984) Exploitation of Warine Communities (Life Sciences Res Rep 32, Dahlem Konferenzen). Berlin: Springer-Verlag. 367 pp.

May, R.M.. Beddington. J.R.. Horwood J.W. and Shepherd J.G. (1978) Exploiting natural populations in an uncertain world. Mathl Biosci. 42. 219-52.

May. R.M. Beddington. J.R.. Clark. C.W., Holt, S.J. and Laws, R.M. ( 1979) Management of multispecies fisheries. Science 205, 267-77.

Mount. D.I. (1992) What evidence of ecosystem risk is necessary to influence regulatory and industrial decisions. Adv. mod. env: Toxicol. 20, 3 l-7.

Muck. P.(1989) Major trends in the pelagic ecosystem off Peru and their implications for management. In Pauly, D.. Muck, P.. Mendo. J. and Tsukayama, I., eds. The Perturian Cipwelling Ecowsistem: Dynamics and Inteructions (ICLARM Conf. Proc. 18). Manila. Philippines: ICLARM. pp. $386-403$.

Murawski. S.A. ( 1984) Mixed species yield-per-recruitment analysis accounting for technological interactions. Can. J. Fish. aquat. Sci. 41, 897-9 16.

Murawski. S.A.. Lange, AM. and Idoine. J.S. (1991) An analysis of technological interactions among Gulf of Maine mixed species fisheries. ICES mar: Sci.Symp. 193. 237-52. 
Murdoch. W.W. and Bence. J. (1987) General predators and unstable prey populations. In Kerfoot. W.C. and Sih. A.. eds. Predution: Direct and Indirect Impacts on Aquatic Communities. Hanover and London: University Press of New England. pp. 17-30.

Myers. R.A., Barrowman. N.J., Hutchings, J.A. and Rosenberg, A.A. (1995) Population dynamics of exploited fish stocks at low population levels. Science 269. 1106-8.

Neher.P.A., Amason, R. and Mollett, N. (1989) Rights Bused Fishing: Proceedings of the NATO Advanced ResearchWorkshop on Scientific Foundations for Rights Based Fishing. Reykjavik. iceland. Junc 27 July I. $1988.541 \mathrm{pp}$.

Nihoul. J.C. (ed.) ( 1975 ), Modelling of Wharine Sistcms. (Elsevier Uccunugraphy Series. 10 ). Amsterdam: Elsevier. 272 pp.

Nikitina, E.N. and Pearse. PH. (1992) Conservation of marine resources in the former Soviet Union: an environmental perspective. Oceun Development and Intern. Luw 23, 369-81.

North Pacific Fisheries Management Council (1994) Ecosystem Considerations 1995: The Plan Teams for the Groundfish Fisheries of the Bering Sea. Aleutian Islands. and the Gulf of Alaska. Seattle: NPFMC. 88 pp.

Oiivieri. R.A., Cohen. A. and Chavez. F.P. (1993) An ecosystem model of Monterey Bay. California. In Christensen, V. and Pauly, D. eds. (1993) Trophic Models of Aquatic Ecosystems (ICLARM Conf. Proc. 26). Manila: ICLARM. pp. 3 15-22.

Overholtz. W.J.. Murawski, S.A. and Foster. K.L. (1991) Impact of predatory fish, marine mammals. and seabirds on the pelagic fish ecosystem of the northeastern USA. ICES mar. Sci. Symp. 193. 198-208.

Overholtz, W.J.. Edwards, S.F. and Brodziak, J.K.T. (1993) Strategies for rebuilding and harvesting New England groundfish resources. In Kruse. G., Eggers, D.M., Marasco, R.J.. Pautzke, C. and Quinn, T.J. II. eds. Management Strategies for Exploited Fish Populations. Fairbanks: University of Alaska, Alaska Sea Grant College Program Report 93-02, pp. 507-27.

Paine, R.T. (1980) Food webs: linkage interaction strength. and community infrastructure. J.Anim. Ecol. 49, 667-85.

Parrish. B.B. (1979) Extracts of a letter from B.B. Parrish, Director, Marine Laboratory, Aberdeen to B.J. Rothschild. In Interim Report of the ACMRR working party on the scientific basis for determining management measures. FAO. Fish. Circ. No. 718.pp.11 1-12.

Pauly, D., Muck, P., Mendo. J. and Tsukayama, I. (eds) (1989) The Peruvian Upwelling Ecosvstem. Dinamics and Interactions (ICLARM Conf. Proc. 18). Manila: ICLARM. 438 pp.

Pikitch. E.K. (1987) Use of a mixed-species yield-per-recruit model to explore the consequences of various management policies for the Oregon flatfish fishery. Can. J. Fish. aquat. Sci. 44 (Supp. 2), 349-59.

Pikitch. E.K. (1991) Technological interactions in the U.S. West Coast groundfish trawl fishery and their implications for management. ICES mar. Sci. Symp. 193, 253-63.

Platt. D.D. (1993) The System in the Sea: Applying Ecosystems Principles to Marine Fisheries. Island Institute Conf., Harvard June 16-28. 1992. Vol. 2. Conf. Proc. Island Institute, Rockford ME. $198 \mathrm{pp}$.

Polovina, J.J. (1984) Model of a coral reef ecosystem: Part I. The ECOPATH model and its application to French Frigate Shoals. Coral Reefs 3, 1-1 I.

Polovina, J.J. (1994) Case of the missing lobsters. Nat. Hist. 2. 51-8.

Pope. J.G. (1991) The ICES multispecies assessment working group: evolution insights and future problems. ICES mar: Sci. Sump. 193. 22-33.

Prescott. V. (1993) Role of national political factors in the management of LMEs: evidence from West Africa. In Sherman, K.. Alexander, L.M. and Gold, B.D., eds. Large Marine Ecosıstems V: Stress. Mitigation and Sustainability. Washington. DC: AAAs Press. pp. 280-98.

Ricker. W.E. (1954) Stock and recruitment. J. Fish. Res. Bd Can. 11, 559-623.

Riffenburgh, R.H. (1969) Stochastic model of interpopulation dynamics in marine ecology. J. Fish. Res. Bd Can. 26, 2843-80. 
Russ, G.R. and Alcala. X.C. (1994) Sumiion Island Reserve: 20 years of hopes and frustrations. NAGA. the ICLARM Quarterly (July). S-12.

Sainsbury, K.J. (1984) The ecological basis of tropical fisheries management. In Pauly. D. and Murphy, G.I.. eds. Theory and Management of Tropical Fisheries (ICLARM Conf. Proc. 9). Manila:ICLARM and Cronulla: Fisheries Division, CSIRO, pp. 167-94.

Sainsbury. K.J. (199 1) Application of an experimental approach to management of a tropical multispecies fishery with highly uncertain dynamics. ICES mar. Sci. Symp. 193. 301-19.

Schindler. D.W. ( 1987) Detecting ecosystem responses to anthropogenic stress. Can. J. Fish. aquat. Sci. 44 (Supp.1), 6-25.

Schindler, D.W. ( 1990) Experimental perturbations of whole lakes as tests of hypothesis concerning ecosystem structure and function. Oikos 57, 25-41.

Schramm. H. ( 1994) President's Message. Ecosystem management and other buzzwords. AFS Fish. Manage. Section Nerisl.13(2), 1.

Sherman. K. (1993) Large marine ecosystems as global units for marine resource management - an ecological perspective. In Sherman. K., Alexander. L.M. and Gold. B.D.. eds. Large Marine Ecosystems V: Stress, Mitigation and Sustainability. Washington. DC: AAAs Press, pp. 3-14.

Sherman. K., Alexander, L.M. and Gold. B.D. (eds) (1993) Large Marine Ecosistems l: Stress. Mitigation and Sustainubility. Washington. DC: AAAs Press. 376 pp.

Simpson. A.C. (1982) A review of the database on tropical multispecies stocks in the southeast Asian region. In Pauly. D. and Murphy. G.I. (eds) Theory and Munagement of Tropical Fisheries (ICLARM Conf. Proc. 9). Manila: ICLARM and Cronulla: Fisheries Division, CSIRO, pp. 5-32.

Sissenwine, M.P. and Daan. N. (1991) An overview of multispecies models relevant to management of living resources. ICES mar. Sci. S.mp. 193. 6-11.

Sissenwine, M.P. and Rosenberg, A.A. (1993) Marine fisheries at a critical juncture. Fisheries 18( IO), 6-14.

Slobodkin, L.B. (1963) Growth und Regulation of Animal Populations. New York: Holt. Rinehart and Winston. 184 pp.

Smith, S.J., Hemt. J.J. and Rivard. D. (eds) (1993) Risk evaluation and biological reference points for fisheries management. Can. spec. Publ. Fish. aquut. Sci. 120. 442 pp.

Sparre. P. (1991) Introduction to multispecies virtual population analysis. ICES.mar. Sci. Simp. 193. $12-21$.

Steele, J.H. (ed.) (1970) Marine Food Chains. Edinburgh: Oliver and Boyd. 552 pp.

Sugihara, G. (1984) Ecosystems dynamics group report. In May. R.M. (ed.) Exploitation of Marine Communities (Life Science Research Report 32, Dahlem Konferenzen 1984). Berlin: Springer Verlag, pp. 13 1-53.

Townsend, R.E. and Pooley. S.G. (1994) Effort reduction under limited entry: attrition versus fractional licenses in the Hawaii long line fleet. N. Am. J. Fish. Manage. 14, 297-306.

Travis, J. ( 1993) Invader threatens Black. Azov Seas. Science 262. 1366-7.

Tullock, G. and Brady, G. ( 1992) The risk of crying wolf. Advmod. env. Toxicol. 20. 77-91.

Ulanowicz, R.E. (1986) Growth and Development: Ecosystem Phenomenonology. New York: SpringerVerlag. 203 pp.

Ulanowicz, R.E. and Platt. T. (eds) (1985) Ecosystem theory for biological oceanography. Can. Bull. Fish. aquat. Sci. 213: 260 pp.

Ulanowicz, R.E. and Puccia. C.J. (1990) Mixed trophic impacts in ecosystems. Coenoses 5, 7-16.

Van Dyne. G.M. (ed.) (1969) The Ecos:stem Concept in Natural Resource Management. New York: Academic Press. 383 pp.

Walters, C.J. and Hilborn. R. (1978) Ecological optimization and adaptive management. Ann. Rev. Ecol. Syst. 9. 157-88.

Watt, K.E.F. (1908) Ecology und Resource Management. New York: McGraw Hill. 450 pp.

Wilson, J.A., French. J., Kleban, I?. McKay, S.R. and Townsend R. (1991) Chaotic dynamics in a multiple species fishery: a model of community predation. Ecol.Modelling 58. 303-22. 
Wooster, W.S. ( 1993) Is it food' An overview. In Is it Food? Addressing Marine Mammal and Seabird Declines. Workshop Summary. Fairbanks: Alaska Sea Grant Report 93-01, pp. 1-3.

Wulff. F.. Field. J.G. and Mann, K.H. (eds) (1989) Nerwork Analysis in Marine Ecologn: Methods and Applications. Berlin: Springer-Verlag. 284 pp.

Accepted 20 October 1995 